\title{
Proteomic analysis of differentially expressed proteins in the serum of patients with acute renal allograft rejection using iTRAQ labelling technology
}

\author{
YUE ZHANG $^{1}$, MINGLIN OU ${ }^{1}$, HUA LIN ${ }^{1}$, LIUSHENG LAI ${ }^{1}$, HUAIZHOU CHEN ${ }^{1}$, \\ JIEJING CHEN ${ }^{1}$, WEIGUO SUI ${ }^{1}$, WEN XUE ${ }^{1}$, RUOHAN ZHANG ${ }^{1}$, QING GAN $^{1}$, \\ DONGE TANG ${ }^{2}$, XUYONG SUN $^{3}$, JIANHUI DONG ${ }^{3}$, QIANG YAN ${ }^{1}$ and YONG DAI ${ }^{1,2}$
}

\begin{abstract}
${ }^{1}$ Department of Nephrology, Guilin No. 924 Hospital, Guangxi Key Laboratory of Metabolic Diseases Research, Guilin Key Laboratory of Kidney Disease Research, Guilin, Guangxi 541002; ${ }^{2}$ Department of Clinical Medical Research Center, The Second Clinical Medical College of Jinan University (Shenzhen People's Hospital), Shenzhen, Guangdong 518020;

${ }^{3}$ Department of Organ Transplantation, Institute of Transplant Medicine, No. 923 Hospital of People's Liberation Army, Guangxi Key Laboratory for Transplantation Medicine, Guangxi Transplantation Medicine Research Center of Engineering Technology, Nanning, Guangxi 530021, P.R. China
\end{abstract}

Received September 12, 2018; Accepted April 7, 2020

DOI: $10.3892 / \mathrm{mmr} .2020 .11299$

\begin{abstract}
Transplantation is currently the best treatment for patients with end-stage renal disease. However, acute rejection (AR) is the major source of failure in renal transplantation. The current best practice for the diagnosis of AR involves renal biopsy, but it is invasive, time-consuming, costly and inconvenient. Sensitive and less invasive detection of AR episodes in renal transplant patients is essential to preserve allograft function. The present study applied isobaric tags for relative and absolute quantitation (iTRAQ) mass spectrometry to analyze serum protein expression in patients with AR and healthy controls. Overall, 1,399 proteins were identified. Using
\end{abstract}

Correspondence to: Professor Yong Dai, Department of Clinical Medical Research Center, The Second Clinical Medical College of Jinan University (Shenzhen People's Hospital), 1017 Dongmen Road (North), Shenzhen, Guangdong 518020, P.R. China

E-mail: daiyong22@aliyun.com

Dr Qiang Yan, Department of Nephrology, Guilin No. 924 Hospital, Guangxi Key Laboratory of Metabolic Diseases Research, Guilin Key Laboratory of Kidney Disease Research, 1 Xinqiaoyuan Road, Guilin, Guangxi 541002, P.R. China

E-mail: yanqiang1967@sina.com

Abbreviations: AR, acute rejection; GO, Gene Ontology; COGs, Clusters of Orthologous Groups of proteins; iTRAQ, isobaric tags with related and absolute quantitation; LC-ESI-MS/MS, liquid chromatography electrospray ionization tandem mass spectrometry; KRT1, keratin 1; Lp(a), lipoprotein (a); VDBP, vitamin D-binding protein

Key words: acute rejection, renal allograft, isobaric tags with related and absolute quantitation, proteomics, serum a cut-off of $\mathrm{Q}<0.05$ and a fold change of $>1.2$ for the variation in expression, 109 proteins were identified to be differentially expressed between the AR and control groups, 72 of which were upregulated and 37 were downregulated. Several proteins, including properdin, keratin 1, lipoprotein(a) and vitamin D-binding protein, may have roles in the pathogenesis of AR. The present study focused on iTRAQ-based proteomic profiling of serum samples in AR. Insight from the present study may help advance the understanding of the molecular mechanisms of AR and identify potential novel biomarkers of AR for further characterization.

\section{Introduction}

At present, transplantation is the best treatment for end-stage renal disease. Survival and quality of life among transplant patients are significantly better than in dialysis patients (1). Despite the routine use of immunosuppressive therapies in the care of post-transplant patients, acute rejection (AR) of the renal allograft still occurs. Sensitive and early detection of AR episodes in patients with renal transplant is essential to preserve allograft function. The majority of patients with AR are asymptomatic and the detection of AR critically relies on regular monitoring for increases in serum creatinine, an insensitive laboratory biomarker of renal injury, as a sign of renal hypofunction $(2,3)$. The current best practice for diagnosis of AR is renal biopsy, but this is invasive, time-consuming, costly and inconvenient. Therefore, noninvasive and sensitive methods would be valuable for the early detection of AR.

Biomarkers may be used for noninvasive prediction or diagnosis of AR in patients with kidney transplantation (4). Suitable candidate biomarker(s) should be based on a simple and cost-effective assay, requiring the noninvasive collection of a test sample, yet it should be specific and sensitive, as the results may prolong graft survival and improve patient health. 
Proteomics have been widely employed in numerous fields of medical research (5-7). It is an interdisciplinary area for the discovery of candidate biomarkers that may be applied for noninvasive diagnoses.

Isobaric tags for relative and absolute quantitation (iTRAQ) is a multiplexed protein quantitative mass spectrometry (MS) technology based on isobaric reagents (8). It may be used to measure eight samples in one experiment (9). The iTRAQ reagent consists of a reporter group, a balance group and a peptide reactive group (PRG) (8). The reporter group ions that are generated appear as peaks in the low-mass region (113, $114,115,116,117,118,119$ and $121 \mathrm{Da})(10,11)$. As this region is free of other common fragment ions, signals found in this region are only due to contributions from the reporter ions from the corresponding labeled sample digests (12). Therefore, the relationships can be quantified by comparing the peak area of one reporter group peak with another. The ratio of one peak area to another represents the relative amount of a given peptide in each of the corresponding sample digests (12). The balance group ensures that an iTRAQ reagent-labeled peptide, whether labeled with iTRAQ reagent $114,115,116$ or 117 , displays at the same mass (12). The PRG covalently links an iTRAQ reagent isobaric tag with each lysine side chain and $\mathrm{N}$-terminal group of a peptide. Multiple peptides in a sample digest are labeled (12). The advantage of iTRAQ is that it allows for concurrent quantization of complex samples but requires only a small amount of sample (13). Previous studies have indicated that quantitative proteomics using iTRAQ technology has the potential for diagnosis and treatment with AR after kidney transplantation $(14,15)$. Therefore, the present study performed a quantitative proteomic analysis with an iTRAQ-based liquid chromatography electrospray ionization tandem MS (LC-ESI-MS/MS) approach to detect proteins differentially expressed in the serum of patients with AR and healthy individuals with no kidney transplant. Insight from the present study may help advance the understanding of the pathogenic mechanisms of AR and identify potential novel approaches for early diagnosis of AR.

\section{Materials and methods}

Serum sample collection. A total of 12 subjects, including patients with AR (1 male and 2 females; age, 51-61 years) and 9 age and gender matched healthy controls ( 6 males and 3 females; age, 40-55 years) were enrolled in the present study. All healthy controls were enrolled from the Guilin No. 924 Hospital (Guilin, China), with no prior history of chronic disease. Their characteristics are listed in Table I. The primary disease of the patients with AR was chronic glomerulonephritis. All patients with AR had received hemodialysis for $>2$ years prior to kidney transplantation and had no infectious diseases (such as hepatitis or tuberculosis) or autoimmune diseases. All kidney grafts were from donation after cardiac death of the donors and the patients had no history of organ transplantation. All patients with AR received tacrolimus, methylprednisolone and mycophenolate mofetil, to maintain triple immunosuppressive therapy. None of the subjects had a history of smoking or drinking. Serum specimens were collected from the Department of Nephrology at Guilin No. 924 Hospital (Guilin, China) between March and September in 2015. The study was performed in accordance with the Declaration of Helsinki and was approved by the Medical Ethics Committee of Guilin No. 924 Hospital (Guilin, China). Written informed consent was obtained from all participants. The serum samples $(5 \mathrm{ml})$ were collected in serum separator Vacutainer tubes and were separated by centrifugation at $250 \mathrm{x}$ g at $20^{\circ} \mathrm{C}$ for $10 \mathrm{~min}$. Serum was divided into $0.5-\mathrm{ml}$ aliquots and stored at $-80^{\circ} \mathrm{C}$ until further analysis.

Protein preparation and tryptic digestion. Serum samples were disrupted in lysis buffer ( $7 \mathrm{M}$ urea, $2 \mathrm{M}$ thiourea, $0.2 \%$ SDS, $20 \mathrm{mM}$ Tris) with enzyme inhibitors (1X protease inhibitor Cocktail, $1 \mathrm{mM}$ EDTA). After centrifuging the mixtures at $25,000 \mathrm{x} \mathrm{g}$ at $4^{\circ} \mathrm{C}$ for $20 \mathrm{~min}$, the supernatants were mixed with 5 volumes of cold acetone and stored at $-20^{\circ} \mathrm{C}$ for $2 \mathrm{~h}$ to overnight. The mixtures were centrifuged at $25,000 \mathrm{x} \mathrm{g}$ for $20 \mathrm{~min}$ at $4^{\circ} \mathrm{C}$, and the protein pellets were dissolved with lysis buffer, to which $10 \mathrm{mM}$ dithiothreitol was added, prior to incubation at $56^{\circ} \mathrm{C}$ for $1 \mathrm{~h}$ in order to reduce the disulfide bonds of peptides. Then $55 \mathrm{mM}$ iodoacetamide was added to the solution prior to storage in the dark for $45 \mathrm{~min}$, followed by addition of 5 volumes of chilled acetone and storage at $-20^{\circ} \mathrm{C}$ for $2 \mathrm{~h}$. The solution was centrifuged at 25,000 x g for $20 \mathrm{~min}$ at $4^{\circ} \mathrm{C}$ and the pellet was dissolved with lysis buffer to obtain the protein solution. The protein concentration of the supernatant was determined with the Bradford assay method.

For each sample, $100 \mu \mathrm{g}$ protein was digested with Trypsin Gold at a ratio of protein/trypsin of $20: 1$ at $37^{\circ} \mathrm{C}$ for $4 \mathrm{~h}$. Fresh Trypsin Gold was added with the ratio of protein/trypsin of 20:1 again and the mixture was incubated at $37^{\circ} \mathrm{C}$ for an additional $8 \mathrm{~h}$.

iTRAQ labelling and peptide fractionation. The peptides were vacuum centrifuged to dryness after trypsin digestion. The product was redissolved with $0.5 \mathrm{M}$ triethylammonium bicarbonate and the iTRAQ labelling of peptide samples was performed using iTRAQ Reagent 8-plex kit (AB SCIEX) in accordance with the manufacturer's protocol. The peptides of the healthy controls were labelled with iTRAQ-113 isobaric tags and those from patients with AR with iTRAQ-121 isobaric tags and incubated for $2 \mathrm{~h}$ at $20^{\circ} \mathrm{C}$. The iTRAQ-labelled peptides were fractionated using reversed-phase (RP) chromatography.

For RP chromatography using a Shimadzu LC-20AB HPLC Pump system (Shimadzu Corp.), $100 \mu \mathrm{g}$ digested peptides were reconstituted with $2 \mathrm{ml}$ buffer A [5\% acetonitrile $(\mathrm{ACN}), 95 \% \mathrm{H}_{2} \mathrm{O}$, adjusted to $\mathrm{pH} 9.8$ with ammonia] and loaded onto a $4.6 \times 250 \mathrm{~mm}$ Gemini $\mathrm{C}_{18}$ column containing $5-\mu \mathrm{m}$ particles (Phenomenex Inc.). The peptides were eluted at $20^{\circ} \mathrm{C}$ at a flow rate of $1 \mathrm{ml} / \mathrm{min}$ with a gradient of $5 \%$ buffer $\mathrm{B}\left(5 \% \mathrm{H}_{2} \mathrm{O}, 95 \% \mathrm{ACN}\right.$, adjusted to 9.8 with ammonia) for $10 \mathrm{~min}$, followed by a $5-35 \%$ buffer B gradient for $40 \mathrm{~min}$ and a $35-95 \%$ buffer B gradient for $1 \mathrm{~min}$. The system was maintained in $95 \%$ buffer B for 3 min, which was switched to $5 \%$ within 1 min prior to equilibrating with $5 \%$ buffer B for $10 \mathrm{~min}$. Elution was monitored by measuring the absorbance at $214 \mathrm{~nm}$ and a different vial was used every min. The eluted peptides in 20 fractions were pooled and vacuum-dried.

LC-ESI-MS/MS analysis. Each fraction was resuspended in buffer A [5\% ACN, $0.1 \%$ formic acid (FA)] and centrifuged 
Table I. Basic characteristics of patients and healthy controls.

\begin{tabular}{lcc}
\hline Characteristic & $\begin{array}{c}\text { Patients with acute rejection } \\
(\mathrm{n}=3)\end{array}$ & $\begin{array}{c}\text { Healthy controls } \\
(\mathrm{n}=9)\end{array}$ \\
\hline Gender (male/female) & $1 / 2$ & $7 / 2$ \\
Age (years) & $53.0 \pm 7.2$ & $47.3 \pm 5.3$ \\
Serum creatinine $(\mu \mathrm{mol} / \mathrm{l})\left(42-130 \mu \mathrm{mol} / \mathrm{l}^{\mathrm{a}}\right)$ & $222.7 \pm 82.5$ & $89.4 \pm 10.3$ \\
Blood urea nitrogen $(\mathrm{mmol} / \mathrm{l})\left(2.5-8.2 \mathrm{mmol} / \mathrm{l}^{\mathrm{a}}\right)$ & $20.3 \pm 4.9$ & $4.6 \pm 0.8$ \\
Uric acid $(\mu \mathrm{mol} / \mathrm{l})\left(\mathrm{male}, 208-440 \mathrm{mmol} / \mathrm{l} ;\right.$ female, $\left.155-360 \mathrm{mmol} / \mathrm{l}^{\mathrm{a}}\right)$ & $410.7 \pm 81.3$ & $346.0 \pm 84.7$ \\
\hline
\end{tabular}

${ }^{a}$ The normal ranges.

at $20,000 \mathrm{x}$ g for $10 \mathrm{~min}$ at $4^{\circ} \mathrm{C}$, and the final concentration of peptides was $\sim 0.5 \mathrm{~g} / \mathrm{l}$. The supernatant was loaded on a LC-20AD nanoHPLC (Shimadzu Corp.) by an autosampler onto a $2-\mathrm{cm} \mathrm{C}_{18}$ trap column. The peptides were purified using an $18-\mathrm{cm}$ analytical $\mathrm{C}_{18}$ column (inner diameter $75 \mu \mathrm{m}$, packed in-house). The samples were loaded and elution was performed in the following order: $8 \mu \mathrm{l} / \mathrm{min}$ for $4 \mathrm{~min}, 41 \mathrm{~min}$ gradient running at $300 \mathrm{nl} / \mathrm{min}$ from 5 to $35 \% \mathrm{~B}(95 \% \mathrm{ACN}, 0.1 \% \mathrm{FA}), 5$ min linear gradient to $80 \%$ buffer B (maintained for $5 \mathrm{~min}$ ), followed by a return to $5 \%$ within 1 min.

Data acquisition was performed with a TripleTOF 5600 System (AB SCIEX) fitted with a Nanospray III source (AB SCIEX) and a pulled quartz tip as the emitter (New Objectives), and controlled with Analyst 1.6 software (AB SCIEX). Data were acquired under the following MS conditions: Ion spray voltage, $2.5 \mathrm{kV}$; curtain gas, 30 psi; nebulizer gas, $15 \mathrm{psi}$; and interface heater temperature, $150^{\circ} \mathrm{C}$. The resolution was $\sim 30,000$. For information-dependent acquisition, survey scans were acquired at $250 \mathrm{msec}$ and 30 production scans were collected if exceeding a threshold of 120 counts/sec and with a $2+$ to $5+$ charge state. The total cycle time was set to $3.3 \mathrm{sec}$. The Q2 transmission window was 100 Da for $100 \%$. A total of four time bins for each scan was performed at a pulse frequency value of $11 \mathrm{kHz}$ through monitoring of the $40 \mathrm{GHz}$ multichannel TDC detector with four-anode channel detection. An iTRAQ adjust rolling collision energy was applied to all precursor ions for collision-induced dissociation. The dynamic exclusion set for $1 / 2$ of peak width $(15 \mathrm{sec})$.

Proteomics data analysis. After separating the peptides, identification and quantification of detected proteins were performed. The MS/MS spectra were searched using Mascot software (version 2.3.02; Matrix Science, Ltd.). For protein identification, the search parameters were as follows: Fragment mass tolerance of 0.1 Da, peptide mass tolerance of $0.05 \mathrm{Da}$, MS/MS Ion as the type of search, trypsin as the enzyme, mass values of monoisotopic, variable modifications of iTRAQ8plex (Y) and oxidation (M), fixed modifications of iTRAQ8plex (K), iTRAQ8plex (N-term) and carbamidomethyl (C) and database of human201512 (132,191 sequences). Protein identifications were considered reliable if they involved at least one unique peptide. An automated software called IQuant (16) was used for quantitatively analyzing the labeled peptides with isobaric tags. It integrates Mascot Percolator (17) and advanced statistical algorithms to process the MS/MS signals generated from the peptides labeled by isobaric tags. The main IQuant quantitation parameters were as follows: Quant_peptide of all unique peptides, Quant_number of at least one unique spectrum, Variance stabilization normalization, Protein_Ratio of weighted average and permutation tests as Statistical Analysis. High-confidence peptide identification was obtained by setting a false discovery rate of $<1 \%$ at the peptide level. At least one unique peptide per protein group was required for identification of proteins and two quantified peptides for quantification of proteins. Functional enrichment analysis was performed using the Clusters of Orthologous Groups of proteins (COGs) (https://www.ncbi.nlm.nih.gov/COG) and the Gene Ontology (GO) (http://www.geneontology.org/) database. Pathway analysis was also performed by Kyoto Encyclopedia of Genes and Genomes (KEGG) mapping (http://www.genome.jp/kegg/). For biological pathway analysis and GO term enrichment, $\mathrm{P}<0.05$ was considered to indicate a statistically significant difference.

\section{Results}

Protein identification and quantification. Using Mascot Percolator (17), 1,399 proteins were identified and quantified with the cutoff of $\mathrm{Q} \leq 0.01$ (Table SI). A total of 604 identified proteins contained $>1$ peptide, including 259 proteins with $\geq 5$ peptides, 63 proteins with 4 peptides, 95 proteins with 3 peptides and 187 proteins with 2 peptides. Using a strict cut-off of a 1.2-fold change in expression and $\mathrm{Q}<0.05,109$ proteins [including 72 upregulated proteins (Tables II and SII) and 37 downregulated proteins (Tables III and SIII)] were found differentially expressed in AR specimens compared with those in the control samples. As presented in Fig. 1, a volcano plot of the $\log 2$ fold-change (x-axis) vs. - $\log 10 \mathrm{Q}$-value (y-axis) was used to depict the differentially expressed proteins (DEPs).

Gene ontology analysis. These DEPs were analyzed by GO annotation and categorized into 'molecular function', 'cellular component' and 'biological process'. 'Molecular function' describes activities, such as catalysis or binding, that occur at the molecular level. In this category, the proteins were indicated to be involved in 16 terms, including binding activity $(48.95 \%)$, catalytic activity $(27.27 \%)$, enzyme regulator activity 
Table II. Upregulated proteins in patients with acute rejection and control subjects.

\begin{tabular}{|c|c|c|c|c|}
\hline Protein & Description & Protein coverage $(\%)$ & Unique peptides & Q-value \\
\hline P35908 & Keratin, type II cytoskeletal 2 epidermal & 22.8 & 9 & 0.004 \\
\hline $\mathrm{P} 02741$ & C-reactive protein & 43.3 & 9 & 0.001 \\
\hline Q14520 & Hyaluronan-binding protein 2 & 19.6 & 10 & 0.001 \\
\hline P27918 & Properdin & 25.4 & 8 & 0.001 \\
\hline Q7L523 & Ras-related GTP-binding protein A & 1.9 & 1 & 0.001 \\
\hline Q53G71 & Calreticulin variant (fragment) & 35.2 & 10 & 0.001 \\
\hline P10645 & Chromogranin-A & 9.4 & 1 & 0.001 \\
\hline Q1HP67 & Lipoprotein, Lp(A) & 6.2 & 10 & 0.001 \\
\hline B4DUV1 & Fibulin-1 & 40.1 & 7 & 0.001 \\
\hline K7ER74 & Protein APOC4-APOC2 & 55.6 & 5 & 0.001 \\
\hline P12259 & Coagulation factor $\mathrm{V}$ & 25.9 & 46 & 0.001 \\
\hline P08311 & Cathepsin G & 26.7 & 6 & 0.001 \\
\hline P04004 & Vitronectin & 57.5 & 16 & 0.001 \\
\hline F5H6X6 & Neutral alpha-glucosidase $\mathrm{AB}$ & 14.0 & 9 & 0.036 \\
\hline P13645 & Keratin, type I cytoskeletal 10 & 35.6 & 12 & 0.001 \\
\hline P02790 & Hemopexin & 41.6 & 15 & 0.001 \\
\hline P69905 & Alpha-2 globin chain & 67.6 & 7 & 0.001 \\
\hline Q12794 & Hyaluronidase & 26.4 & 7 & 0.001 \\
\hline P20742 & Pregnancy zone protein & 29.8 & 25 & 0.001 \\
\hline A0A0C4DH43 & Uncharacterized protein (Fragment) & 36.1 & 1 & 0.007 \\
\hline H6VRG3 & Keratin 1 & 43.9 & 1 & 0.001 \\
\hline P03950 & Ribonuclease A A1 & 44.9 & 6 & 0.001 \\
\hline P00450 & $\mathrm{CP}$ protein & 49.7 & 32 & 0.001 \\
\hline D6RF35 & Vitamin D-binding protein & 65.5 & 2 & 0.004 \\
\hline P02675 & $\begin{array}{l}\text { Epididymis secretory sperm binding } \\
\text { protein } \mathrm{Li} 78 \mathrm{p}\end{array}$ & 67.2 & 22 & 0.001 \\
\hline B4E380 & Histone H3 & 11.5 & 2 & 0.009 \\
\hline P14618 & Pyruvate kinase & 46.9 & 4 & 0.001 \\
\hline B2RDW0 & $\begin{array}{l}\text { cDNA, FLJ96792, highly similar to } \\
\text { Homo sapiens calmodulin } 2 \text { (phosphorylase } \\
\text { kinase, delta), mRNA }\end{array}$ & 53.0 & 5 & 0.038 \\
\hline P00734 & Prothrombin & 93.2 & 36 & 0.001 \\
\hline Q5NV62 & V3-4 protein (fragment) & 18.2 & 1 & 0.001 \\
\hline P01008 & $\begin{array}{l}\text { Serpin peptidase inhibitor, clade C } \\
\text { (antithrombin), member } 1 \text {, isoform CRA_a }\end{array}$ & 89.4 & 23 & 0.001 \\
\hline $\mathrm{P} 02656$ & Apolipoprotein C-III & 99.9 & 9 & 0.001 \\
\hline P00451 & Coagulation factor VIII & 10.3 & 13 & 0.001 \\
\hline Q96IY4 & Carboxypeptidase B2 & 25.8 & 11 & 0.001 \\
\hline P61626 & C-type lysozyme & 52.0 & 3 & 0.001 \\
\hline Q8WVW5 & Putative uncharacterized protein (fragment) & 65.8 & 5 & 0.001 \\
\hline P62805 & Histone H4 & 69.9 & 7 & 0.001 \\
\hline Q15113 & Procollagen C-endopeptidase enhancer 1 & 41.4 & 12 & 0.001 \\
\hline P34096 & $\begin{array}{l}\text { Full-length cDNA clone CSODF032YM23 } \\
\text { of fetal brain of Homo sapiens (human) }\end{array}$ & 55.1 & 6 & 0.001 \\
\hline B0YIW1 & Apolipoprotein A-V variant 3 & 37.7 & 11 & 0.001 \\
\hline B2R773 & $\begin{array}{l}\text { cDNA, FLJ93312, highly similar to Homo sapiens } \\
\text { adipose most abundant gene transcript } 1, \text { mRNA }\end{array}$ & 19.3 & 3 & 0.001 \\
\hline P68871 & Hemoglobin, beta & 84.4 & 2 & 0.004 \\
\hline G8JLA2 & Myosin light polypeptide 6 & 33.6 & 5 & 0.002 \\
\hline P35527 & Keratin, type I cytoskeletal 9 & 31.0 & 14 & 0.001 \\
\hline O00391 & Sulfhydryl oxidase 1 & 46.7 & 28 & 0.001 \\
\hline B2R9V7 & Superoxide dismutase $[\mathrm{Cu}-\mathrm{Zn}]$ & 17.1 & 4 & 0.001 \\
\hline
\end{tabular}


Table II. Continued.

\begin{tabular}{|c|c|c|c|c|}
\hline Protein & Description & Protein coverage $(\%)$ & Unique peptides & Q-value \\
\hline F2RM37 & Coagulation factor IX & 32.1 & 12 & 0.001 \\
\hline P08670 & Epididymis luminal protein 113 & 27.3 & 8 & 0.001 \\
\hline Q6N095 & Putative uncharacterized protein DKFZp686K03196 & 37.7 & 1 & 0.002 \\
\hline P55056 & Apolipoprotein C-IV & 52.8 & 5 & 0.001 \\
\hline P02649 & Apolipoprotein E & 100 & 9 & 0.001 \\
\hline P13798 & N-acylaminoacyl-peptide hydrolase, isoform CRA_b & 10.2 & 7 & 0.003 \\
\hline P23142 & Fibulin-1 & 31.7 & 7 & 0.001 \\
\hline B3KRF9 & $\begin{array}{l}\text { cDNA FLJ34156 fis, clone FCBBF3013266, } \\
\text { highly similar to Tsukushi (leucine-rich repeat- } \\
\text { containing protein 54) }\end{array}$ & 31.2 & 7 & 0.037 \\
\hline Q8NG19 & Multi-functional protein MFP & 33.7 & 7 & 0.004 \\
\hline Q86UD1 & Out at first protein homolog & 31.1 & 6 & 0.001 \\
\hline C9JEU5 & Fibrinogen gamma chain & 31.5 & 2 & 0.019 \\
\hline P20160 & Azurocidin & 22.3 & 5 & 0.040 \\
\hline P55072 & Epididymis luminal protein 220 & 33.7 & 6 & 0.001 \\
\hline B2RA39 & $\begin{array}{l}\text { cDNA, FLJ94686, highly similar to Homo sapiens } \\
\text { complement factor H-related 5, mRNA }\end{array}$ & 17.6 & 9 & 0.001 \\
\hline A0A075B785 & $\begin{array}{l}\text { LisH domain and HEAT repeat-containing } \\
\text { protein KIAA1468 }\end{array}$ & 1.2 & 1 & 0.003 \\
\hline P02671 & Fibrinogen alpha chain & 30.7 & 15 & 0.003 \\
\hline P04406 & GAPDH & 57.0 & 14 & 0.001 \\
\hline P11586 & C-1-tetrahydrofolate synthase, cytoplasmic & 6.1 & 5 & 0.017 \\
\hline Q02818 & Nucleobindin-1 & 25.4 & 9 & 0.006 \\
\hline P05164 & Myeloperoxidase & 64.0 & 31 & 0.001 \\
\hline B3KQ20 & $\begin{array}{l}\text { cDNA FLJ32635 fis, clone SYNOV2000178, } \\
\text { highly similar to Proteoglycan-4 }\end{array}$ & 34.6 & 13 & 0.001 \\
\hline A0A024R7F1 & Protein kinase C substrate $80 \mathrm{~K}-\mathrm{H}$, isoform CRA_a & 14.0 & 6 & 0.007 \\
\hline H9KV75 & Alpha-actinin-1 & 26.5 & 9 & 0.001 \\
\hline B4DWH0 & $\begin{array}{l}\text { cDNA FLJ55670, highly similar to EGF-containing } \\
\text { fibulin-like extracellular matrix protein } 1\end{array}$ & 42.9 & 10 & 0.001 \\
\hline Q13103 & Secreted phosphoprotein 24 & 32.2 & 6 & 0.001 \\
\hline Q9UBX5 & Fibulin 5, isoform CRA_b & 14.1 & 6 & 0.017 \\
\hline
\end{tabular}

cDNA, complementary DNA; EGF, epidermal growth factor; APOC, apolipoprotein C; CP, ceruloplasmin.

$(5.85 \%)$ and structural molecule activity (4.03\%; Fig. 2A). In the category 'cellular component', the proteins were enriched in 16 terms and the majority of them were located in the cell part $(17.43 \%)$, cell $(17.43 \%)$, organelle $(12.96 \%)$ and organelle part (9.60\%; Fig. 2B). In the category 'biological process', 23 terms were enriched, with $10.68 \%$ of the proteins participating in the cellular process, followed by single-organism process $(9.82 \%)$, metabolic process $(9.61 \%)$ and biological regulation (8.10\%; Fig. 2C).

COG analysis. COGs were delineated by comparing protein sequences encoded in complete genomes, representing major phylogenetic lineages. COGs comprise a framework for functional and evolutionary genome analysis. In the analysis of COGs, all identified proteins were classified into 23 functional categories (Table IV), including posttranslational modification, protein turnover, chaperones (149 proteins,
$20.67 \%$ ), general function prediction only (119 proteins, $16.50 \%$ ), energy production and conversion (56 proteins, $7.77 \%$ ) and signal transduction mechanisms (47 proteins, $6.52 \%)$.

Pathway enrichment analysis. The KEGG database was used to identify the pathways in which the DEPs were involved. The results indicated that of these proteins were accumulated in 290 different pathways. The majority of the proteins were involved in 'Complement and coagulation cascades' (30 proteins, 18.18\%), 'Staphylococcus aureus infection' (23 proteins, 13.94\%), 'Systemic lupus erythematosus' (22 proteins, 13.33\%) and 'Amoebiasis' (21 proteins, 12.73\%). The top 30 DEPs in the KEGG pathway enrichment are presented in Table V.Protein interactions have an important role in certain biological functions, including immune response, blood coagulation, inflammatory response, ion homeostasis, cholesterol metabolism, actin binding, cell 
Table III. Downregulated proteins in patients with acute rejection and control subjects.

\begin{tabular}{|c|c|c|c|c|}
\hline Protein & Description & $\begin{array}{c}\text { Protein } \\
\text { coverage }(\%)\end{array}$ & $\begin{array}{l}\text { Unique } \\
\text { peptides }\end{array}$ & Q-value \\
\hline B4DRV4 & $\begin{array}{l}\text { cDNA FLJ55667, highly similar to secreted protein acidic and } \\
\text { rich in cysteine }\end{array}$ & 44.8 & 7 & 0.001 \\
\hline H7C3N9 & Leucine-rich repeat flightless-interacting protein 2 (fragment) & 8.2 & 1 & 0.036 \\
\hline Q71M29 & Putative uncharacterized protein FP3420 & 4.3 & 1 & 0.027 \\
\hline P05109 & Protein S100-A8 & 11.8 & 1 & 0.032 \\
\hline P22792 & Carboxypeptidase $\mathrm{N}$ subunit 2 & 27.2 & 11 & 0.001 \\
\hline D3JV43 & C-X-C motif chemokine (fragment) & 35.3 & 2 & 0.027 \\
\hline $\mathrm{B} 2 \mathrm{R} 8 \mathrm{I} 2$ & $\begin{array}{l}\text { cDNA, FLJ93914, highly similar to Homo sapiens } \\
\text { histidine-rich glycoprotein, mRNA }\end{array}$ & 36.0 & 2 & 0.033 \\
\hline B4DPP8 & cDNA FLJ53075, highly similar to kininogen-1 & 44.1 & 16 & 0.001 \\
\hline P02765 & Alpha-2-HS-glycoprotein & 39.5 & 8 & 0.001 \\
\hline Q6MZL2 & Putative uncharacterized protein DKFZp686M0562 (fragment) & 28.0 & 4 & 0.001 \\
\hline P00739 & Haptoglobin-related protein & 72.1 & 9 & 0.016 \\
\hline P09871 & Complement $\mathrm{C} 1 \mathrm{~s}$ subcomponent & 37.9 & 18 & 0.001 \\
\hline P06396 & Gelsolin & 35.2 & 1 & 0.001 \\
\hline Q9UNU2 & Complement protein C4B frameshift mutant (fragment) & 61.6 & 1 & 0.038 \\
\hline P27169 & Serum paraoxonase/arylesterase 1 & 52.1 & 11 & 0.001 \\
\hline A4D1F6 & Leucine-rich repeat and death domain-containing protein 1 & 0.7 & 1 & 0.017 \\
\hline $\mathrm{P} 02760$ & Protein AMBP & 33.0 & 8 & 0.001 \\
\hline F5GXQ5 & Glycine N-acyltransferase-like protein 3 (fragment) & 3.2 & 1 & 0.001 \\
\hline O95445 & Apolipoprotein M & 60.1 & 6 & 0.001 \\
\hline O43866 & CD5 antigen-like & 43.5 & 13 & 0.001 \\
\hline V9H1C1 & Gelsolin exon 4 (fragment) & 46.4 & 1 & 0.017 \\
\hline F1C4A7 & Monocyte differentiation antigen CD14 & 29.6 & 9 & 0.020 \\
\hline P01024 & Epididymis secretory sperm binding protein $\mathrm{Li} 62 \mathrm{p}$ & 87.9 & 98 & 0.001 \\
\hline Q5T985 & Inter-alpha-trypsin inhibitor heavy chain $\mathrm{H} 2$ & 44.4 & 31 & 0.001 \\
\hline B7Z539 & $\begin{array}{l}\text { cDNA FLJ56954, highly similar to Inter-alpha-trypsin } \\
\text { inhibitor heavy chain H1 }\end{array}$ & 49.9 & 2 & 0.011 \\
\hline B2R815 & $\begin{array}{l}\text { cDNA, FLJ93695, highly similar to Homo sapiens serpin } \\
\text { peptidase inhibitor, clade A (alpha-1 antiproteinase, antitrypsin), } \\
\text { member } 4 \text {, mRNA }\end{array}$ & 37.9 & 14 & 0.001 \\
\hline A0A0A0MSP7 & FERM and PDZ domain-containing protein 3 (fragment) & 0.3 & 1 & 0.010 \\
\hline P80108 & Phosphatidylinositol-glycan-specific phospholipase D & 38.1 & 24 & 0.001 \\
\hline $\mathrm{P} 02652$ & Apolipoprotein A-II & 99.9 & 8 & 0.001 \\
\hline P51884 & Lumican & 32.2 & 9 & 0.001 \\
\hline B4DU16 & $\begin{array}{l}\text { cDNA FLJ54550, highly similar to Homo sapiens fibronectin } 1 \text {, } \\
\text { transcript variant } 6 \text {, mRNA }\end{array}$ & 78.7 & 1 & 0.004 \\
\hline Q96PD5 & $\mathrm{N}$-acetylmuramoyl-L-alanine amidase & 35.1 & 10 & 0.001 \\
\hline A0A087WXI2 & IgGFc-binding protein & 2.6 & 9 & 0.010 \\
\hline P01031 & Complement C5 & 50.1 & 69 & 0.001 \\
\hline P15169 & Carboxypeptidase $\mathrm{N}$ catalytic chain & 24.0 & 8 & 0.010 \\
\hline A0A024R462 & Fibronectin 1, isoform CRA_n & 69.7 & 50 & 0.001 \\
\hline A8K1K1 & $\begin{array}{l}\text { cDNA FLJ76342, highly similar to Homo sapiens carnosine } \\
\text { dipeptidase } 1 \text { (metallopeptidase M20 family), mRNA }\end{array}$ & 42.8 & 17 & 0.001 \\
\hline
\end{tabular}

cDNA, complementary DNA; AMBP, alpha-1-microglobulin.

motility, energy metabolism, RNA post-transcriptional modification, amino acid metabolism, small molecule biochemistry, cellular growth and proliferation (18-21). A pathway enrichment analysis of DEPs was implemented based on the KEGG database in AR patients and healthy controls (Fig. 3). All abbreviations are shown in Table SIV. 


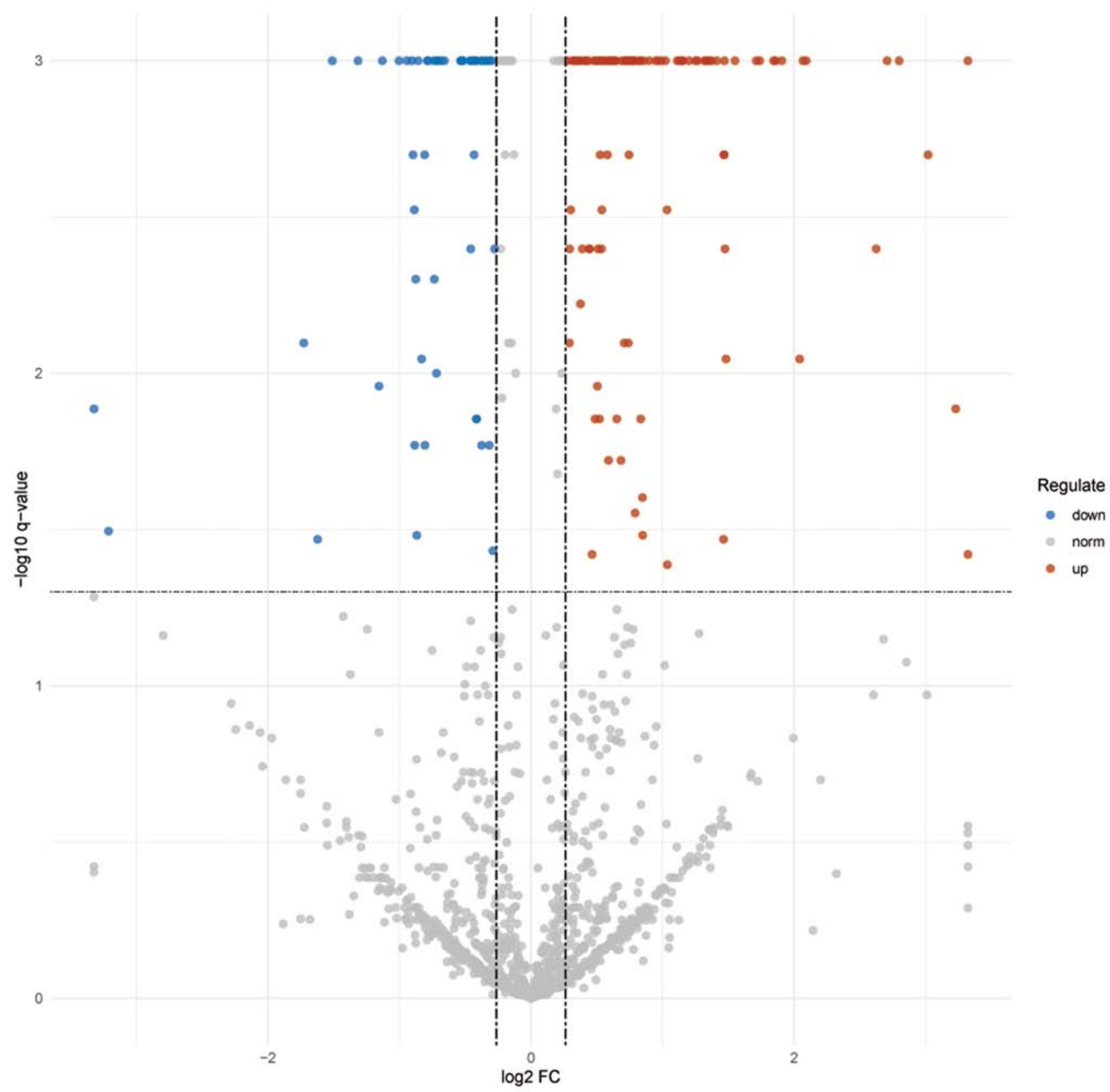

Figure 1. Volcano plot of DEPs. This plot depicts the $\log 2 \mathrm{FC}$ (x-axis) vs. $-\log 10 \mathrm{Q}$ value (y-axis, representing the probability that the protein is differentially expressed). $\mathrm{Q} \leq 0.05$ and $\mathrm{FC} \geq 1.2$ were set as the significant threshold for differential expression. Dots in red denote significantly upregulated proteins which passed the screening threshold. Dots in green denote significantly downregulated proteins which passed the screening threshold. Gray dots indicate non-significantly DEPs. FC, fold change; up, upregulated; down, downregulated; norm, not differentially expressed; DEP, differentially expressed protein.

\section{Discussion}

The major impediment to success in kidney graft is acute graft rejection, which leads to loss of the organ occur mainly in the first year after transplantation (22). The lack of applicable biomarkers to predict rejection is the biggest challenge in AR. Renal biopsy offers an accurate detection method for AR but the invasiveness of this procedure and other adverse effects may limit its use in certain patients (23-25). Therefore, the reliable and timely identification of potential early biomarkers for rejection is essential. A number of studies have been performed over the past decade (26-29); the majority of them depend on the combination of stable isotopes for obtaining mass spectrometric ordering and relative quantification $(30,31)$. Of these,
iTRAQ technology, which is based on the labelling of peptides in up to 8 proteomes at the MS/MS level for relative and absolute quantization, is the most widely used for numerous types of diseases (18-20,32-34). Wu et al (14) used iTRAQ technology to detect DEPs in the plasma of patients with acute renal allograft rejection. The results demonstrated that NF- $\mathrm{KB}$, and signal transducer and activator of transcription 1 and 3, are potential markers for AR and may lead to novel strategies for diagnosis and treatment. Freue et al (15) quantitated the relative plasma concentrations of proteins in patients with acute renal allograft rejection by using iTRAQ labeling and quantitative proteomic technology. The study indicated that the profiling of the plasma proteome provided a promising method to monitor the immunological course in patients with 
A

Molecular function

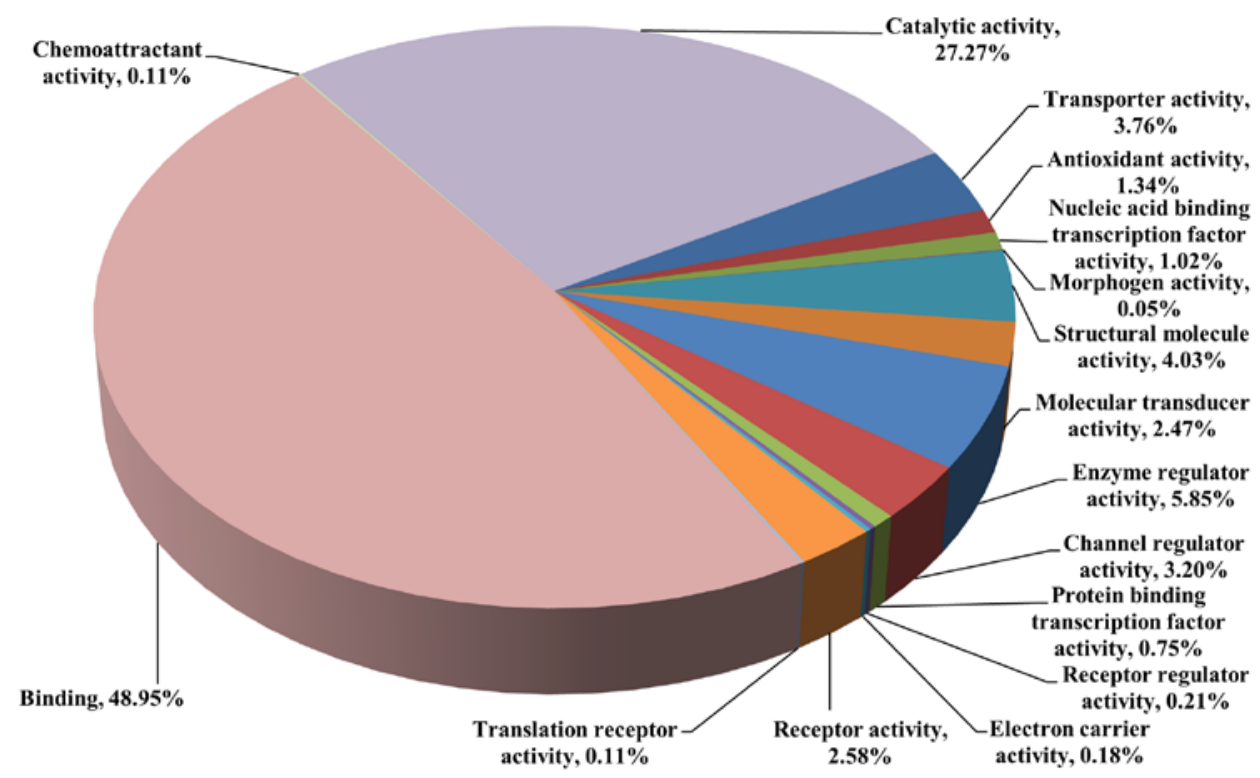

B

Cellular component

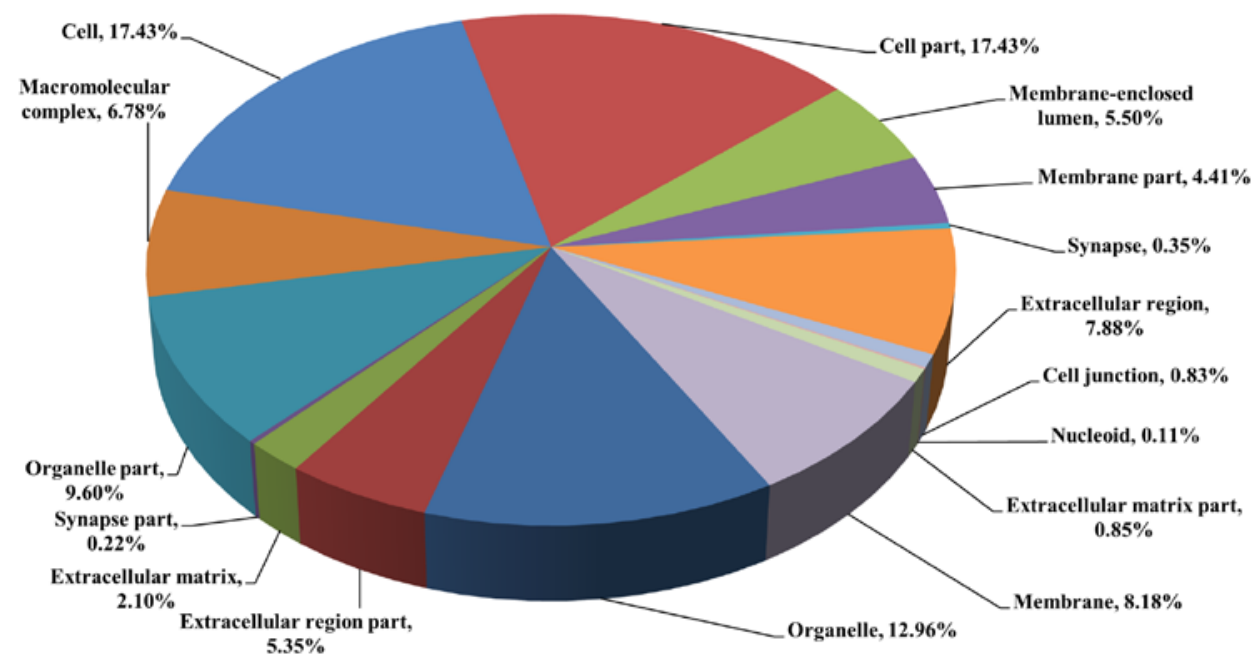

C

Biological process

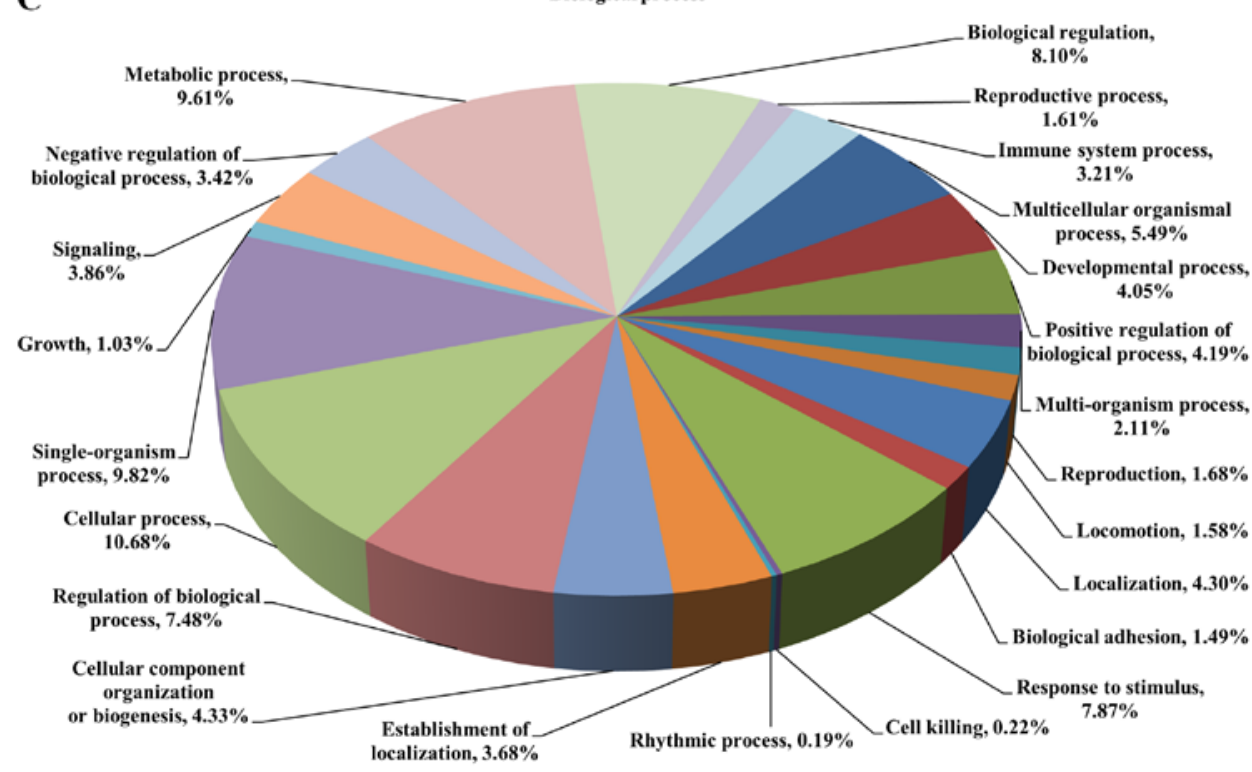

Figure 2. Bioinformatics analysis of differentially expressed proteins. Gene Ontology terms in the categories (A) Molecular function, (B) Cellular component and (C) Biological process. 
Table IV. Protein number for each Cluster of Orthologous Groups of proteins function category.

\begin{tabular}{|c|c|c|}
\hline Code & Functional category & Number of proteins \\
\hline A & RNA processing and modification & 1 \\
\hline B & Chromatin structure and dynamics & 9 \\
\hline $\mathrm{C}$ & Energy production and conversion & 56 \\
\hline $\mathrm{D}$ & Cell cycle control, cell division, chromosome partitioning & 19 \\
\hline $\mathrm{E}$ & Amino acid transport and metabolism & 42 \\
\hline $\mathrm{F}$ & Nucleotide transport and metabolism & 20 \\
\hline $\mathrm{G}$ & Carbohydrate transport and metabolism & 37 \\
\hline $\mathrm{H}$ & Coenzyme transport and metabolism & 12 \\
\hline I & Lipid transport and metabolism & 23 \\
\hline $\mathrm{J}$ & Translation, ribosomal structure and biogenesis & 26 \\
\hline $\mathrm{K}$ & Transcription & 21 \\
\hline $\mathrm{L}$ & Replication, recombination and repair & 22 \\
\hline M & Cell wall/membrane/envelope biogenesis & 13 \\
\hline $\mathrm{N}$ & Cell motility & 4 \\
\hline $\mathrm{O}$ & Posttranslational modification, protein turnover, chaperones & 149 \\
\hline $\mathrm{P}$ & Inorganic ion transport and metabolism & 7 \\
\hline Q & Secondary metabolites biosynthesis, transport and catabolism & 15 \\
\hline $\mathrm{R}$ & General function prediction only & 119 \\
\hline $\mathrm{S}$ & Function unknown & 24 \\
\hline $\mathrm{T}$ & Signal transduction mechanisms & 47 \\
\hline $\mathrm{U}$ & Intracellular trafficking, secretion, and vesicular transport & 9 \\
\hline $\mathrm{Y}$ & Nuclear structure & 1 \\
\hline $\mathrm{Z}$ & Cytoskeleton & 45 \\
\hline
\end{tabular}

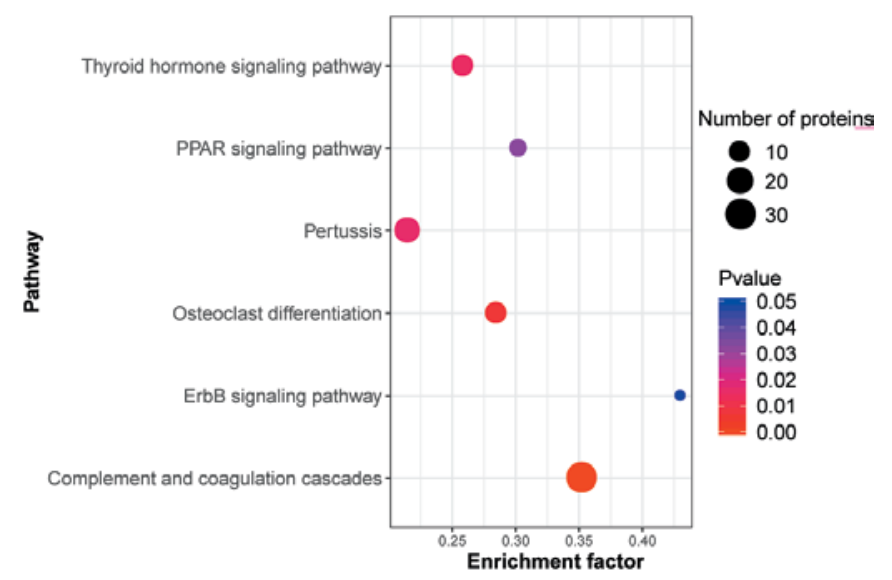

Figure 3. Statistics of pathway enrichment of DEPs in patients with acute rejection and control subjects. The vertical axis represents the name of the pathway and the horizontal axis represents the corresponding enrichment factors. The enrichment factor is the ratio of the number of DEPs annotated to this pathway term to the total number of proteins annotated to this pathway term. A higher enrichment factor indicates greater intensiveness, a lower P-value means greater intensiveness. The dot size represents the number of DEPs annotated to the pathway. PPAR, peroxisome proliferator-activated receptor; DEP, differentially expressed protein.

AR following renal allograft. The present study performed a proteomics analysis using iTRAQ technology and several proteins were identified as potential candidate biomarkers for the accurate diagnosis of AR. In the present study, 109 proteins with a fold change $\geq 1.2$ were identified, 72 of which were upregulated and 37 were downregulated. GO analysis in the category 'biological process' revealed that alterations in the expression of identified proteins in patients with AR were involved in diverse biological processes, including a single-organism process, cellular process, biological regulation and metabolic process, confirming that the pathogenesis of AR is associated with different molecular mechanisms. Some of these proteins, including properdin and keratin 1 (KRT1), may have the potential to be used as a serum biomarker in the diagnosis of AR.

Complement proteins have an important role in the ischemia/reperfusion injury (IRI) (35), which prominently contributes to morbidity and mortality in acute renal allograft failure (36). Properdin is a $\gamma$-globulin protein made up of multiple identical monomeric subunits and is a stabilizer of surface-bound $\mathrm{C} 3 \mathrm{bBb}$. It facilitates the complement alternative pathway for C3-convertase formation (37). Properdin is the only known positive regulator of complement activation (38). Miwa et al (39) suggested that properdin has a major pathogenic role during early renal IRI and anti-properdin therapy may have a beneficial effect in human IRI. Consistent with the literature, properdin was also significantly upregulated in the serum of patients with AR in the present study. According to these results, it may be hypothesized that high levels of properdin may be significantly involved in the development of AR. However, its specific roles in AR have not been well studied and require to be further investigated. 
Table V. Top 30 DEPs mapped to pathways.

\begin{tabular}{|c|c|c|c|c|}
\hline Pathway & $\begin{array}{l}\text { DEPs with } \\
\text { pathway annotation }\end{array}$ & $\begin{array}{l}\text { All proteins with } \\
\text { pathway annotation }\end{array}$ & P-value & Pathway ID \\
\hline Complement and coagulation cascades & $30(18.18)$ & $86(6.63)$ & $2.940498 \mathrm{e}-08^{\mathrm{a}}$ & ko04610 \\
\hline Osteoclast differentiation & $11(6.67)$ & $39(3.00)$ & $0.006834358^{\mathrm{a}}$ & ko04380 \\
\hline Thyroid hormone signaling pathway & $11(6.67)$ & $43(3.31)$ & $0.01483172^{\mathrm{a}}$ & ko04919 \\
\hline Pertussis & $18(10.91)$ & $85(6.55)$ & $0.01614457^{\mathrm{a}}$ & ko05133 \\
\hline PPAR signaling pathway & $6(3.64)$ & $20(1.54)$ & $0.03239792^{\mathrm{a}}$ & ko03320 \\
\hline ErbB signaling pathway & $3(1.82)$ & $7(0.54)$ & $0.04790133^{\mathrm{a}}$ & ko04012 \\
\hline Systemic lupus erythematosus & $22(13.33)$ & $125(9.63)$ & 0.06066206 & ko05322 \\
\hline Malaria & $9(5.45)$ & $41(3.16)$ & 0.06572233 & ko05144 \\
\hline Salivary secretion & $3(1.82)$ & $8(0.62)$ & 0.0696401 & ko04970 \\
\hline VEGF signaling pathway & $3(1.82)$ & $8(0.62)$ & 0.0696401 & ko04370 \\
\hline Regulation of actin cytoskeleton & $18(10.91)$ & $100(7.70)$ & 0.07168303 & ko04810 \\
\hline mTOR signaling pathway & $2(1.21)$ & $4(0.31)$ & 0.08102746 & ko04150 \\
\hline Herpes simplex infection & $5(3.03)$ & $19(1.46)$ & 0.08226199 & ko05168 \\
\hline $\begin{array}{l}\text { Chagas disease (American } \\
\text { trypanosomiasis) }\end{array}$ & $4(2.42)$ & $14(1.08)$ & 0.090641 & ko05142 \\
\hline Staphylococcus aureus infection & $23(13.94)$ & $139(10.71)$ & 0.09910894 & ko05150 \\
\hline Glucagon signaling pathway & $4(2.42)$ & $15(1.16)$ & 0.1118566 & ko04922 \\
\hline MicroRNAs in cancer & $10(6.06)$ & $52(4.01)$ & 0.1129492 & ko05206 \\
\hline Phototransduction - fly & $2(1.21)$ & $5(0.39)$ & 0.1239715 & ko04745 \\
\hline Protein export & $1(0.61)$ & $1(0.08)$ & 0.1271186 & ko03060 \\
\hline $\begin{array}{l}\text { Glycosylphosphatidylinositol(GPI)- } \\
\text { anchor biosynthesis }\end{array}$ & $1(0.61)$ & $1(0.08)$ & 0.1271186 & ko00563 \\
\hline Leukocyte transendothelial migration & $15(9.09)$ & $87(6.70)$ & 0.1274251 & ko04670 \\
\hline Proteoglycans in cancer & $15(9.09)$ & $88(6.78)$ & 0.1370228 & ko05205 \\
\hline Rap1 signaling pathway & $14(8.48)$ & $82(6.32)$ & 0.1463614 & ko04015 \\
\hline Amoebiasis & $21(12.73)$ & $132(10.17)$ & 0.1525601 & ko05146 \\
\hline Focal adhesion & $16(9.70)$ & $97(7.47)$ & 0.1572612 & ko04510 \\
\hline HIF-1 signaling pathway & $5(3.03)$ & $23(1.77)$ & 0.1576914 & ko04066 \\
\hline Hippo signaling pathway & $7(4.24)$ & $36(2.77)$ & 0.1626743 & ko04390 \\
\hline Renin secretion & $2(1.21)$ & $6(0.46)$ & 0.1708845 & ko04924 \\
\hline Type II diabetes mellitus & $2(1.21)$ & $6(0.46)$ & 0.1708845 & ko04930 \\
\hline Renin-angiotensin system & $2(1.21)$ & $6(0.46)$ & 0.1708845 & ko04614 \\
\hline
\end{tabular}

${ }^{\mathrm{a}} \mathrm{P}<0.05$. DEP, differentially expressed protein. Values are expressed as $\mathrm{n}(\%)$.

Another significantly upregulated protein in AR identified in the present study was KRT1, which belongs to the keratin family. KRT1 is polymorphic (40) and has been reported to be expressed in endothelial cells (41). KRT1 is involved in the lectin complement pathway caused by oxidative stress in endothelial cells (42). Transplant recipients may have antibodies to endothelial cells (43-47). Guo et al (48) indicated that KRT1 antibodies were probably autoantibodies and the presence of KRT1 antibodies is significantly associated with deterioration of kidney allograft function. Analysis of the LC-ESI-MS/MS data indicated that KRT1 was differentially expressed between AR patients and healthy controls. This protein may be a valuable diagnostic marker for monitoring patients' conditions but its possible role in allograft rejection requires further investigation.

In addition, certain novel candidate protein markers identified in the present study, including lipoprotein (a) [Lp(a)] and vitamin D-binding protein (VDBP), were significantly upregulated between AR patients and healthy controls. Previous studies have revealed that $\mathrm{Lp}$ (a) promotes atherosclerotic diseases, including stroke and coronary heart disease $(49,50)$. Shimoyamada et al (51) reported that smooth muscle cell proliferation could be induced by $\mathrm{Lp}$ (a) as a mechanism of atherosclerosis in the rejected kidney. The deposition of $\mathrm{Lp}(\mathrm{a})$ in lesions in vascular rejection of transplanted kidneys is similar to that in atherosclerotic lesions. VDBP is a multifunctional protein $(52,53)$ that occurs in serum, cerebrospinal fluid and ascitic fluid, and is characterized as being capable of binding various forms of vitamin D (54). 1,25-dihydroxycholecalciferol $\left[1,25-(\mathrm{OH})_{2} \mathrm{D}_{3}\right.$; also known as calcitriol] is one of the active forms of vitamin $\mathrm{D}$ in the kidney. Previous studies have revealed that $1,25-(\mathrm{OH})_{2} \mathrm{D}_{3}$ has an essential role in immunoregulation and allograft rejection $(55,56)$, and VDBP may be 
one of the serum biomarker candidates of acute renal allograft rejection. These candidate proteins may provide a scientific foundation for the pathogenic mechanisms and potential therapeutic approach for AR that warrant further research.

The proteins identified as differentially expressed in patients with AR may be involved in the process of AR and have an important role in the development of the condition. In this study, the healthy controls were healthy individuals with no kidney transplant. Patients with kidney transplant but no AR were not included in the control group because these patients had other health conditions that were unsuitable for the control group. In future studies, it would be ideal to collect adequate specimens from patients with kidney transplant but no AR and with no other health conditions. One limitation of the present study was the small population due to AR being rare in the clinic and the number of patients with AR that met the selection requirements being small. The low sample numbers limit the ability to classify stages of acute renal allograft rejection. Due to the small sample size, it was not possible to determine the correlations of the levels of DEPs with multifarious risk factors or with a specific immune response in detail. If the number of samples was to be increased, different stages of acute renal allograft rejection would be able to be observed, different factors such as gender or age would be considered, and a more objective evaluation could be made for the iTRAQ labelling technique in acute renal allograft rejection. In addition, further validation studies are required to elucidate the mechanisms of the DEPs involved in the biological processes of acute renal allograft rejection, facilitating the development of novel biomarkers for rejection. Therefore, increasing the number of samples will be necessary in further research to obtain more objective and reliable results.

In conclusion, iTRAQ combined with LC-ESI-MS/MS has proven to be a potential and efficient quantitative proteomic technique. The iTRAQ labelling technique was applied to explore the pathogenic mechanisms of AR. The results proved that different protein profile alternations and different pathways were involved in AR. Certain representative candidates, including properdin, KRT1, Lp(a) and VDBP, may serve as potential and novel biomarkers for the early detection of AR.

\section{Acknowledgements}

Not applicable.

\section{Funding}

This study was supported by the National Natural Science Foundation of China (grant no. 81670596), the Natural Science Foundation of Guangxi (grant no. 2017GXNSFAA198185), the Science and Technology Development Project of Guangxi (grant no. 14124003-8) and the Scientific Research and Technology Development Project of Guilin (grant no. 20170117-1).

\section{Availability of data and materials}

The mass spectrometry proteomics data were deposited with the ProteomeXchange Consortium via the PRIDE partner repository (https://www.ebi.ac.uk/pride/archive) with the dataset identifier PXD015336.

\section{Authors' contributions}

The present study was conceived by YD and QY; the experiments were planned by $\mathrm{YZ}, \mathrm{MO}, \mathrm{HL}$ and LL; sample collection and experiments were performed by YZ, HL, HC, JC, WX, RZ, QG, DT, XS and JD; data analysis and interpretation were performed by YZ, MO, LL and WS; the manuscript was drafted by YZ, MO and HL. All aspects of the work were supervised by YD and QY. All authors read and approved the final manuscript.

\section{Ethics approval and consent to participate}

This study was performed according to the Declaration of Helsinki and was approved by the Medical Ethical Committee of Guilin No. 924 Hospital (Guilin, China). Written informed consent was obtained from all participants.

\section{Patient consent for publication}

Not applicable.

\section{Competing interests}

The authors declare that they have no competing interests.

\section{References}

1. Wolfe RA, Ashby VB, Milford EL, Ojo AO, Ettenger RE, Agodoa LY, Held PJ and Port FK: Comparison of mortality in all patients on dialysis, patients on dialysis awaiting transplantation, and recipients of a first cadaveric transplant. N Engl J Med 341: 1725-1730, 1999.

2. Hariharan S, Kasiske B, Matas A, Cohen A, Harmon W and Rabb H: Surrogate markers for long-term renal allograft survival. Am J Transplant 4: 1179-1183, 2004.

3. Josephson MA: Monitoring and managing graft health in the kidney transplant recipient. Clin J Am Soc Nephrol 6: 1774-1780, 2011.

4. Saundh BK, Baker R, Harris M, Welberry Smith MP, Cherukuri A and Hale A: Early BK polyomavirus (BKV) reactivation in donor kidney is a risk factor for development of BKV-associated nephropathy. J Infect Dis 207: 137-141, 2013.

5. Sui W, Zhang R, Chen J, He H, Cui Z, Ou M, Li W, Qi S, Wen J, Lin X and Dai Y: Quantitative proteomic analysis of Down syndrome in the umbilical cord blood using iTRAQ. Mol Med Rep 11: 1391-1399, 2015.

6. Tremlett H, Dai DL, Hollander Z, Kapanen A, Aziz T Wilson-McManus JE, Tebbutt SJ, Borchers $\mathrm{CH}$, Oger J and Cohen Freue GV: Serum proteomics in multiple sclerosis disease progression. J Proteomics 118: 2-11, 2015.

7. Lin XC, Sui WG, Qi SW, Tang DE, Cong S, Zou GM, Zhang Y, Li H, Chen WB, Cheng ZQ and Dai Y: Quantitative proteomic profiling of renal tissue in human chronic rejection biopsy samples after renal transplantation. Transplant Proc 47: 323-331, 2015.

8. Ross PL, Huang YN, Marchese JN, Williamson B, Parker K, Hattan S, Khainovski N, Pillai S, Dey S, Daniels S, et al: Multiplexed protein quantitation in Saccharomyces cerevisiae using amine-reactive isobaric tagging reagents. Mol Cell Proteomics 3: 1154-1169, 2004.

9. Choe L, D'Ascenzo M, Relkin NR, Pappin D, Ross P, Williamson B, Guertin S, Pribil P and Lee KH: 8-plex quantitation of changes in cerebrospinal fluid protein expression in subjects undergoing intravenous immunoglobulin treatment for Alzheimer's disease. Proteomics 7: 3651-3660, 2007.

10. Spanos C and Moore JB: Sample preparation approaches for iTRAQ labeling and quantitative proteomic analyses in systems biology. Methods Mol Biol 1394: 15-24, 2016.

11. Desouza LV, Voisin SN and Siu KW: iTRAQ-labeling for biomarker discovery. Methods Mol Biol 1002: 105-114, 2013. 
12. Applied Biosystems iTRAQ ${ }^{\mathrm{TM}}$ Reagents Amine-modifying labeling reagents for multiplexed relative and absolute protein quantification chemistry reference guide. Applied Biosystems, Part Number 4351918 Rev. A, 2004.

13. Zhang L, Jiang H, Xu G, Chu N, Xu N, Wen H, Gu B, Liu J, Mao S, Na R, et al: iTRAQ-based quantitative proteomic analysis reveals potential early diagnostic markers of clear-cell Renal cell carcinoma. Biosci Trends 10: 210-219, 2016.

14. Wu D, Zhu D, Xu M, Rong R, Tang Q, Wang X and Zhu T: Analysis of transcriptional factors and regulation networks in patients with acute renal allograft rejection. J Proteome Res 10: $175-181,2011$.

15. Freue GV, Sasaki M, Meredith A, Günther OP, Bergman A, Takhar M, Mui A, Balshaw RF, Ng RT, Opushneva N, et al: Proteomic signatures in plasma during early acute renal allograft rejection. Mol Cell Proteomics 9: 1954-1967, 2010.

16. Wen B, Zhou R, Feng Q, Wang Q, Wang J and Liu S: IQuant: An automated pipeline for quantitative proteomics based upon isobaric tags. Proteomics 14: 2280-2285, 2014

17. Brosch M, Yu L, Hubbard T and Choudhary J: Accurate and sensitive peptide identification with mascot percolator. J Proteome Res 8: 3176-3181, 2009.

18. Shen L, Liao L, Chen C, Guo Y, Song D, Wang Y, Chen Y, Zhang K, Ying M, Li S, et al: Proteomics Analysis of Blood Serums from Alzheimer's Disease Patients Using iTRAQ Labeling Technology. J Alzheimers Dis 56: 361-378, 2017.

19. Wang J, Yu L, Huang X, Wang Y and Zhao J: Comparative proteome analysis of saccular intracranial aneurysms with iTRAQ quantitative proteomics. J Proteomics 130: 120-128, 2016.

20. Wang X, Zhi Q, Liu S, Xue SL, Shen C, Li Y, Wu C, Tang Z, Chen W, Song JL, et al: Identifcation of specifc biomarkers for gastric adenocarcinoma by ITRAQ proteomic approach. Sci Rep 6: 38871, 2016.

21. Chen J, Ge L, Liu A, Yuan Y, Ye J, Zhong J, Liu L and Chen X: Identification of pathways related to $\mathrm{FAF} 1 / \mathrm{H}$. pylori-associated gastric carcinogenesis through an integrated approach based on iTRAQ quantification and literature review. J Proteomics 131: 163-176, 2016.

22. Perez JD, Sakata MM, Colucci JA, Spinelli GA, Felipe CR Carvalho VM, Cardozo KH, Medina-Pestana JO, Tedesco-Silva H Jr, Schor N and Casarini DE: Plasma proteomics for the assessment of acute renal transplant rejection. Life Sci 158: 111-120, 2016.

23. Williams WW, Taheri D, Tolkoff-Rubin N and Colvin RB: Clinical role of the renal transplant biopsy. Nat Rev Nephrol 8: $110-121,2012$.

24. Nankivell BJ and Alexander SI: Rejection of the kidney allograft. N Engl J Med 363: 1451-1462, 2010.

25. Schwarz A, Gwinner W, Hiss M, Radermacher J, Mengel M and Haller H: Safety and adequacy of renal transplant protocol biopsies. Am J Transplant 5: 1992-1996, 2005

26. Muenchhoff J,Poljak A, Song F, Raftery M,Brodaty H,Duncan M, McEvoy M, Attia J, Schofield PW and Sachdev PS: Plasma protein profiling of mild cognitive impairment and Alzheimer's disease across two independent cohorts. J Alzheimers Dis 43 $1355-1373,2015$

27. Feng X, Zhang J, Chen WN and Ching CB: Proteome profiling of Epstein-Barr virus infected nasopharyngeal carcinoma cell line: Identification of potential biomarkers by comparative iTRAQ-coupled 2D LC/MS-MS analysis. J Proteomics 74 567-576, 2011

28. Jing L, Parker CE, Seo D, Hines MW, Dicheva N, Yu Y, Schwinn D, Ginsburg GS and Chen X: Discovery of biomarker candidates for coronary artery disease from an APOE-knock out mouse model using iTRAQ-based multiplex quantitative proteomics. Proteomics 11: 2763-2776, 2011.

29. Ye H, Sun L, Huang X, Zhang $P$ and Zhao X: A proteomic approach for plasma biomarker discovery with 8-plex iTRAQ labeling and SCX-LC-MS/MS. Mol Cell Biochem 343: 91-99, 2010.

30. Couttas TA, Raftery MJ, Erce MA and Wilkins MR: Monitoring cytoplasmic protein complexes with blue native gel electrophoresis and stable isotope labelling with amino acids in cell culture: Analysis of changes in the $20 \mathrm{~S}$ proteasome. Electrophoresis 32 : 1819-1823, 2011

31. Albaum SP, Hahne H, Otto A,Haußmann U, Becher D, Poetsch A, Goesmann A and Nattkemper TW: A guide through the computational analysis of isotope-labeled mass spectrometry-based quantitative proteomics data: An application study. Proteome Sci 9: 30, 2011
32. Jin J, Ku YH, Kim Y, Kim Y, Kim K, Lee JY, Cho YM, Lee HK, Park KS and Kim Y: Differential proteome profiling using iTRAQ in microalbuminuric and normoalbuminuric type 2 diabetic patients. Exp Diabetes Res 2012: 168602, 2012.

33. Leong S, Nunez AC, Lin MZ, Crossett B, Christopherson RI and Baxter RC: iTRAQ-based proteomic profiling of breast cancer cell response to doxorubicin and TRAIL. J Proteome Res 11: 3561-3572, 2012

34. Ou M, Zhang X, Dai Y, Gao J, Zhu M, Yang X, Li Y, Yang T and Ding M: Identification of potential microRNA-target pairs associated with osteopetrosis by deep sequencing, iTRAQ proteomics and bioinformatics. Eur J Hum Genet 22: 625-632, 2014.

35. Cernoch $\mathrm{M}$ and Viklicky O: Complement in kidney transplantation. Front Med (Lausanne) 4: 66, 2017.

36. Thadhani R, Pascual M and Bonventre JV: Acute renal failure. $\mathrm{N}$ Engl J Med 334: 1448-1460, 1996.

37. Hourcade DE: The role of properdin in the assembly of the alternative pathway $\mathrm{C} 3$ convertases of complement. J Biol Chem 281: 2128-2132, 2006

38. Lesher AM, Nilsson B and Song WC: Properdin in complement activation and tissue injury. Mol Immunol 56: 191-198, 2013.

39. Miwa T, Sato S, Gullipalli D, Nangaku M and Song WC: Blocking properdin, the alternative pathway, and anaphylatoxin receptors ameliorates renal ischemia-reperfusion injury in decay-accelerating factor and CD59 doubleknockout mice. J Immunol 190: 3552-3559, 2013

40. Han M, Fan L, Qin Z, Lavingia B and Stastny P: Alleles of keratin 1 in families and populations. Hum Immunol 74: 1453-1458, 2013.

41. Remotti F, Fetsch JF and Miettinen M: Keratin 1 expression in endothelia and mesenchymal tumors: An immunohistochemical analysis of healthy and neoplastic tissues. Hum Pathol 32: 873-879, 2001

42. Collard CD, Montalto MC, Reenstra WR, Buras JA and Stahl GL: Endothelial oxidative stress activates the lectin complement pathway: Role of cytokeratin 1. Am J Pathol 159: 1045-1054, 2001.

43. Sun Q, Liu Z, Chen J, Chen H, Wen J, Cheng D and Li L: Circulating anti-endothelial cell antibodies are associated with poor outcome in renal allograft recipients with acute rejection. Clin J Am Soc Nephrol 3: 1479-1486, 2008.

44. Sun Q, Cheng Z, Cheng D, Chen J, Ji S, Wen J, Zheng C, Liu Z. De novo development of circulating anti-endothelial cell antibodies rather than pre-existing antibodies is associated with post-transplant allograft rejection. Kidney Int 79: 655-662, 2011.

45. Sun Q, Liu Z, Yin G, Chen H, Chen J and Li L: Detectable circulating antiendothelial cell antibodies in renal allograft recipients with $\mathrm{C} 4 \mathrm{~d}$-positive acute rejection: A report of three cases. Transplantation 79: 1759-1762, 2005.

46. Glotz D, Lucchiari N, Pegaz-Fiornet B and Suberbielle-Boissel C: Endothelial cells as targets of allograft rejection. Transplantation 82( Suppl 1): S19-S21, 2006.

47. Qin Z, Zou Y, Lavingia B and Stastny P: Identification of endothelial cell surface antigens encoded by genes other than HLA. A combined immunoprecipitation and proteomic approach for the identification of antigens recognized by antibodies against endothelial cells in transplant recipients. Hum Immunol 74 $1445-1452,2013$

48. Guo X, Hu J, Luo W, Luo Q, Guo J, Tian F, Ming Y and Zou Y: Analysis of sera of recipients with allograft rejection indicates that keratin 1 is the target of anti-endothelial antibodies. J Immunol Res 2017: 8679841, 2017.

49. Nordestgaard BG, Chapman MJ, Ray K, Borén J, Andreotti F, Watts GF, Ginsberg H, Amarenco P, Catapano A, Descamps OS, et al: Lipoprotein (a) as a cardiovascular risk factor: Current status. Eur Heart J 31: 2844-2853, 2010.

50. Smolders B, Lemmens R and Thijs V: Lipoprotein (a) and stroke: A meta-analysis of observational studies. Stroke 38: 1959-1966, 2007.

51. Shimoyamada H, Fan J, Watanabe T and Nagata M: Accelerated atherosclerosis with apoLipoprotein (a) and oxidized low-density lipoprotein deposition in acute rejection of transplanted kidney analogous to atherosclerosis. Clin Transplant 16 (Suppl 8): S35-S39, 2002

52. White $\mathrm{P}$ and Cooke $\mathrm{N}$ : The multifunctional properties and characteristics of vitamin D-binding protein. Trends Endocrinol Metab 11: 320-327, 2000 
53. Speeckaert M, Huang G, Delanghe JR and Taes YE: Biological and clinical aspects of the vitamin D binding protein (Gc-globulin) and its polymorphism. Clin Chim Acta 372: 33-42, 2006.

54. Daiger SP, Schanfield MS and Cavalli-Sforza LL: Group-specific component $(\mathrm{Gc})$ proteins bind vitamin $\mathrm{D}$ and 25 -hydroxyvitamin D. Proc Natl Acad Sci USA 72: 2076-2080, 1975.

55. Mathieu $C$ and Jafari M: Immunomodulation by 1,25 -dihydroxyvitamin D3: Therapeutic implications in hemodialysis and renal transplantation. Clin Nephrol 66: 275-283, 2006.
56. Gao Y, Wu K, Xu Y, Zhou H, He W, Zhang W, Cai L, Lin X, Fang Z, Luo Z, et al: Characterization of acute renal allograft rejection by human serum proteomic analysis. J Huazhong Univ Sci Technolog Med Sci 29: 585-591, 2009.

cC) (i) (5) This work is licensed under a Creative Commons EY NO NO Attribution-NonCommercial-NoDerivatives 4.0 International (CC BY-NC-ND 4.0) License. 